\author{
Przemysław Żebrok \\ (D) https://orcid.org/0000-0003-3783-2217 \\ Uniwersytet Papieski Jana Pawła II w Krakowie
}

\title{
Gen solidarności w polskiej społeczności wiejskiej
}

https://doi.org/10.15633/9788374389952.08

Współczesny świat charakteryzuje się wielorakością, dynamiką oraz nieprzewidywalnością zmian, które zachodzą zarówno w wymiarze indywidualnym, jak i wspólnotowym. W ostatnim czasie złożoność rzeczywistości pogłębiła ogólnoświatowa pandemia, w sposób drastyczny zmieniając życie jednostek oraz całych społeczeństw. Dotychczasowy porządek legł w gruzach, a międzyludzkie kontakty zostały ograniczone bądź zawieszone na czas nieokreślony. W tym kontekście zagadnienia solidarności stają się bardzo aktualne i skłaniają do refleksji. Co więcej, nabierają nowego znaczenia.

Gwałtownie zachodzące procesy dotykają także polskiej wsi. To nie tylko zmiany w sposobie życia i gospodarowania, ale nade wszystko przeobrażenia w szeroko pojętej kulturze, religijności, moralności czy obyczajowości. Konserwatywna do tej pory polska wieś coraz częściej podąża za europejską „nowoczesnością”. Jednak pomimo tej rewolucji cywilizacyjnej mieszkańcy wsi zachowali pewne cechy (kod genetyczny), które dotyczą życia wspólnotowego. Niektóre - ciągle żywe w społeczności wiejskiej - zachowania świadczą o trwałych więzach wspólnotowych, będących z kolei fundamentem solidarności.

Celem niniejszego szkicu jest namysł nad współczesnym znaczeniem solidarności w polskiej społeczności wiejskiej. Skoncentrowano się głównie na kilku ważnych aspektach dotyczących tego fenomenu relacji międzyludzkich. Przede wszystkim solidarność przedstawiona zostaje jako cnota wybitnie chrześcijańska. Podkreślono, że podstawową cechą solidarności jest relacyjność, podjęto także próbę opisania tego zjawiska w kategoriach daru i ofiary. Oprócz teoretycznych rozważań w opracowaniu przytoczono konkretne przykłady zachowań świadczących o solidarności wśród ludzi na wsi. 
Badania w głównej mierze opierają się na obserwacji uczestniczącej oraz przekazie ustnym mieszkańców podcieszyńskich wsi. Terenem objętym badaniami jest Śląsk Cieszyński. Pomimo tego, iż przykłady pochodzą z tego właśnie regionu, analiza opracowania pozwala na uogólnienia do całej wsi polskiej. W wymiarze czasowym praca ta ogranicza się do wspomnień ludzi współcześnie żyjących, czyli okresu od zakończenia drugiej wojny światowej do czasów obecnych.

\section{Historyczne i definicyjne ujęcie solidarności}

Słowo „solidarność" pochodzi od łacińskiego słowa solidare, co tłumaczy się jako spajanie. W bardzo ogólnej definicji oznacza jednomyślność, wzajemne wspieranie się, współdziałanie, zgodność w poglądach, dążeniach czy też postępowaniu. Termin ten ma swoje korzenie w rzymskim prawie zobowiązań - obligatio in solidum, zmuszającym członków rodziny lub innej społeczności do współodpowiedzialności za spłatę długów. Później zasada poczucia obowiązku, zgodnie z którą jednostka ręczy za wspólnotę, a wspólnota za jednostkę, została poszerzona na inne obszary stosunków międzyludzkich.

$\mathrm{Z}$ początku idea solidarności dotyczyła tylko zagadnień robotniczych, obejmując relacje między ludźmi pracy. Podstawowym programem było dążenie do tego, by pracę uwolnić od wyzysku, ciężarów oraz cierpień, których przyczyną i głównym źródłem jest drugi człowiek. Z czasem koncepcja solidarności stała się normą zachowań we wszystkich dziedzinach życia.

W Polsce słowo „solidarność” kojarzy się zazwyczaj z ruchem społecznym końca lat siedemdziesiątych XX wieku bądź też z ogólnopolskim związkiem zawodowym, który powstał w 1980 roku. Solidarnościowy zryw doprowadził do upadku systemu komunistycznego, wywierając w ten sposób istotny wspływ na dzieje Polski i Europy. W ten sposób pojęcie solidarności znalazło swoje miejsce w historii oraz świadomości Polaków.

W czasie stanu wojennego nie tylko logo „Solidarności”, ale także używanie samego słowa było zakazane. Pomimo tego solidarność stała się tematem wielu opracowań, pojawia się w literaturze, poezji, piosenkach. Warto tu wspomnieć o bardzie „Solidarności” Jacku Kaczmarskim oraz takich poetach jak Tomasz Jastrun, Stanisław Barańczak, Adam Zagajewski, Ryszard Krynicki, Ernest Bryll, Jarosław Marek Rymkiewicz, Zbigniew Herbert, Czesław Miłosz. Jan Krzysztof Kelus będzie pisał o „Sentymentalnej Pannie S”, a Marek Grechuta zaśpiewa: Solidarność to / Podobnie czuć i myśleć 
/ Solidarność znaczy / Razem iść do celu / Aż w ciemnym tunelu / Światełko zabłyśnie / Nadzieja na którą / Czekało tak wielu. I wszędzie gdzie ludziom / Niedobrze się wiedzie / Gdzie zżera ich nędza / Choroba i głód / Ludzka solidarność / Pomoże im w biedzie / Jej siła, jej wola / Jej trud uczyni cud.

Znakomitą ilustracją pojęcia solidarności jest koncepcja mikroekonomiczna omawiająca jedną z pułapek społecznych - gdy indywidualny zysk jednego członka społeczności prowadzi do nieszczęścia całej grupy. „Tragedia wspólnego pastwiska” pokazuje wartość współpracy przy korzystaniu ze wspólnych dóbr. Garrett Hardin opisuje istotę solidarności na przykładzie wiejskich wspólnot, które wypasały bydło na wspólnych pastwiskach. Krów pasło się akurat tyle, aby trawa na pastwisku mogła odrastać. Ale jeden z rolników zwiększył swoje stado o jedną krowę, chcąc zwiększyć przychody z mleka. Rolnik był zadowolony, a efekt dla całego pastwiska nie był jeszcze widoczny. Gdy inni mieszkańcy wioski zauważyli nieuczciwe zachowanie, zaczęli postępować podobnie, wypasając na wspólnym pastwisku kolejne krowy. Po jakimś czasie trawa przestała odrastać, a pastwisko wyjałowiło się. W konsekwencji krowy przestały dawać mleko. Nieprzestrzeganie umowy społecznej doprowadziło do tragedii wszystkich mieszkańców.

$\mathrm{Z}$ racji tego, iż celem opracowania nie jest teoretyczna analiza samego pojęcia solidarności, ograniczono się tu tylko do jego ogólnego i skrótowego wyjaśnienia. Szerokie omówienie pojęcia solidarności można znaleźć w opracowaniu Jowity Radzińskiej Solidarność: definicja i konteksty ${ }^{1}$.

\section{Solidarność jako cnota chrześcijańska}

Sens słowa „solidarność” określa sam Chrystus, który mówi: „Jeden drugiego brzemiona noście i tak wypełniajcie prawo Chrystusowe" (Ga 6, 2). Można powiedzieć wręcz, że cecha ta jest znakiem rozpoznawczym uczniów Chrystusa i jawi się jako jedna $\mathrm{z}$ fundamentalnych zasad chrześcijańskiej koncepcji organizacji społecznej ${ }^{2}$. Noszenie cudzych ciężarów może przybierać postać czynnego solidaryzowania się z osobami, które potrzebują naszego wsparcia. Myśl tę rozwija ojciec święty Jan Paweł II w homilii dla ludzi świata pracy w Gdańsku w 1987 roku: „Jeden drugiego brzemiona noście - to zwięzłe zdanie apostoła jest inspiracją dla międzyludzkiej i społecznej solidarności.

1 J. Radzińska, Solidarność: definicja i konteksty, „Etyka” 48 (2014), s. 58-68.

2 Jan Paweł II, Encyklika Centesimus annus, Rzym 1991 (dalej: CA), nr 10. 
Solidarność - to znaczy: jeden i drugi, a skoro brzemię, to brzemię niesione razem, we wspólnocie. A więc nigdy: jeden przeciw drugiemu. Jedni - przeciw drugim. I nigdy brzemię dźwigane przez człowieka samotnie. Bez pomocy drugich. Nie może być walka silniejsza nad solidarność. Nie może być program walki ponad programem solidarności. Inaczej - rosną zbyt ciężkie brzemiona. I rozkład tych brzemion narasta w sposób nieproporcjonalny"3.

Idea solidarności jest zakorzeniona w aksjologii chrześcijańskiej, genetycznie bowiem wywodzi się z przykazania miłości bliźniego ${ }^{4}$. Mówi o niej Leon XIII, nazywając ją „przyjaźnią”; Pius XI używa określenia „miłość społeczna”, zaś Paweł VI pisze o „cywilizacji miłości”. Solidarność określana jest jako pewna forma czy też przejaw miłości. Można powiedzieć nawet, że solidarność chodzi w parze z miłością. Na liczne punkty styczne między solidarnością a miłością wskazuje ojciec święty Jan Paweł II, który stwierdza, że „nie ma solidarności bez miłości” ${ }^{6}$. W podobnym tonie wypowiada się Pius XII, zwracając uwagę, że zapomina się o istnieniu węzłów wzajemnej solidarności i miłości między ludźmi. Jego zdaniem to „pierwszy błąd, przynoszący dziś wielkie i powszechne szkody"

Katechizm Kościoła katolickiego stwierdza, iż solidarność jest cnotą wybitnie chrześcijańską, co znajduje swoje potwierdzenie w życiu Kościoła. W dokumencie tym czytamy: „Zasada solidarności, nazywana także przyjaźnią lub miłością społeczną, jest bezpośrednim wymaganiem braterstwa ludzkiego i chrześcijańskiego" ". Pomimo tego wymogu cnota solidarności przejawia się jednak w dobrej woli człowieka, rodzi się sama, spontanicznie, z serca. Józef Tischner przywołuje biblijny przykład miłosiernego Samarytanina, który ratuje bliźniego, bo taka była jego dobra wola 9 .

Chrześcijaństwo za najwyższą normę uznaje kategorię dobra, co umożliwia budowanie społeczeństwa uniwersalnego - opartego o zasadę solidarności - oraz kształtowanie się personalistycznego podejścia do drugiego człowieka $^{10}$. Jednakże dzisiaj coraz rzadziej odwołuje się do chrześcijańskiej tożsamości i wartości, które jeszcze nie tak dawno były dla większości

\footnotetext{
3 Fragment homilii wygłoszonej przez Jana Pawła II podczas mszy świętej dla świata pracy, dz. cyt.

4 Jan Paweł II, Encyklika Sollicitudo rei socialis, Rzym 1987 (dalej: SRS), nr 40.

CA, nr 10.

6 Jan Paweł II, Pielgrzymki do Ojczyzny, Kraków 2005, s. 1019.

Pius XII, Encyklika Summi pontificatus, nr 28.

8 Katechizm Kościoła katolickiego, nr 1939, Poznań 1994 (dalej: KKK), s. 448.

9 J. Tischner, Etyka solidarności, Kraków 1981, s. 6-7.

10 F. Koneczny, Polskie logos a ethos, Antyk, Komorów 1996, s. 9.
} 
zrozumiałe i bliskie. Obecnie - w wymiarze życia osobistego, rodzinnego i obyczajowego - w dziedzinie hierarchii wartości indywidualne „ja” staje się najwyższą, wręcz jedyną normą myślenia, postępowania i nadawania sensu własnemu życiü ${ }^{11}$.

\section{Relacyjność solidarności}

Czym zatem jest solidarność? Podstawą do zrozumienia tego zagadnienia jest dostrzeżenie zależności człowieka od człowieka ${ }^{12}$. Osoba ludzka jest bowiem tego typu substancją - bytem w sobie i dla siebie - która istnieje i spełnia się tylko $\mathrm{w}$ relacjach $\mathrm{z}$ innymi osobami. Jej właściwa - pełna - egzystencja to trwanie we wspólnocie osób (Karol Wojtyła mówi: communio personarum), bycie $\mathrm{z}$ innymi i dla innych ${ }^{13}$. Zdaniem Jana Pawła II cała ludzka doczesność ma wymiar wspólnotowy i społeczny. W homilii podczas mszy świętej dla świata pracy mówił: „Człowiek nie jest sam, żyje z drugimi, przez drugich, dla drugich"14.

O tym, że nikt nie jest samotną wyspą, przypomina Thomas Merton w tytule jednej ze swoich książek. Co więcej, jesteśmy zespoleni nawet wtedy, gdy tego nie wiemy ${ }^{15}$. Człowiek żyje w społeczności, której mniej lub bardziej świadomie coś daje, ale w zamian wiele zyskuje, korzystając często z pomocy bliźniego. Poznanie tej zależności pomaga dostrzec i zrozumieć znaczenie drugiej osoby. Na powiązania człowieka, który jest z innymi i dla innych, zwraca uwagę Andrzej Derdziuk. Zaznacza, iż solidarność jako cnota ma wymiar społeczny nie tyle przez fakt służenia drugiemu człowiekowi, ale właśnie poprzez pełne odsłonięcie jego relacyjnej natury ${ }^{16}$.

Sprzężenia zachodzące między ludźmi tworzą więzi międzyosobowe, przynależności grupowej, terytorialnej, narodowej. Nie możemy być sami w solidarności, solidarność zawsze dotyczy relacji, których najbardziej trwałym fundamentem jest osoba. Należy przy tym zwrócić uwagę na poprawną koncepcję człowieka w świetle tych powiązań. Zdarza się bowiem, iż w sytuacji nadmiaru relacji człowiek traci z pola widzenia fakt, że przedmiotem

\footnotetext{
11 M. Dziewiecki, Ponowoczesność - człowiek - wychowanie, https://opoka.org.pl/biblioteka/I/ID/ ponowoczesnosc_wychowanie.html, (6.03.2021).

12 K. Gide, Solidaryzm, Lwów 1908, s. 29-30.

13 J. Galarowicz, Zobaczyć w Bogu Cztowieka, „Azymut” (2002) nr 4 (49).

14 Fragment homilii wygłoszonej przez Jana Pawła II podczas mszy świętej dla świata pracy, dz. cyt.

15 J. Tischner, Etyka solidarności. Homo sovieticus, Znak, Kraków 2005.

16 A. Derdziuk, Solidarność jako cnota społeczna, „, Roczniki Teologii Moralnej” (2012) nr 4 (59), s. 20.
} 
jego odniesień jest druga osoba ${ }^{17}$. Współczesne zjawisko obcowania z różnego rodzaju multimedialnymi urządzeniami komputerowymi jako substytutem kontaktów międzyludzkich jest tego najbardziej jaskrawym przykładem.

Solidarnym można być tylko z kimś i dla kogoś. Ten relacyjny charakter solidarności domaga się także określonej etyki, której podporządkowane będą kontakty pomiędzy ludźmi. Nie można być solidarnym z ludźmi bez sumienia. Jak pisze ks. Tischner, z ludźmi bez sumienia można jechać w jednym pociągu, siedzieć przy stole podczas kolacji, czytać książki. To jednak nie jest jeszcze solidarność. Nie każde „my” i nie każde „razem” jest już solidarnością. Autentyczna solidarność jest solidarnością sumień. To zrozumiałe, bo być solidarnym z człowiekiem to zawsze móc liczyć na człowieka, a liczyć na człowieka, to wierzyć, że jest w nim coś stałego, co nie zawodzi ${ }^{18}$.

Solidarność jest wartością etyczną. Ten praktyczny wymiar troski o dobro bliźniego jest postawą moralną okazywaną w życiu społecznym, pod wpływem której przyjmuje on życzliwe nastawienie do drugiego człowieka ${ }^{19}$. Zdaniem Marka Dziewieckiego elementarna analiza danych empirycznych wykazuje, że nie jest możliwe osiągnięcie przez człowieka prywatnego szczęścia w oderwaniu od więzi międzyosobowych, od oczywistych i wspólnych dla danej społeczności wartości, norm moralnych czy regulacji prawnych i obyczajowych ${ }^{20}$. Jednakże relacje, o których tu mowa, w ostatnim czasie zostały mocno ograniczone. Zupełnie nowe zachowania - dystans społeczny, zakaz podawania ręki, zakrywanie twarzy maseczkami - prowadzą do anonimowości, oddalania się ludzi od siebie. Nie służy to budowaniu czy podtrzymywaniu trwałych paranteli.

Interakcja zawsze odnosi się do człowieka i oznacza wzajemne oddziaływanie dwu osób lub większej ich liczby. Są to interakcje o charakterze społecznym. Ten typ interakcji dotyczy małych grup, w których dostrzega się konsensus i solidarność, wyrażające się w jednoznacznej interpretacji norm działania przez wszystkich członków grupy ${ }^{21}$. Można powiedzieć, że całe ludzkie działanie zakłada ciągły kontakt z drugą osobą, a dotyczy to przede wszystkim osób z najbliższej rodziny. Oczywiste jest, iż zalążek relacji rodzi się w rodzinie, która jest jedną z najważniejszych grup pierwotnych, to

17 M. Stepulak, Relacyjność sytemu rodzinnego, „Roczniki Teologiczne” 54 (2007) z.10, s. 93-119.

18 J. Tischner, Etyka solidarności. Homo sovieticus, Znak, Kraków 2005.

19 A. Derdziuk, Solidarność jako cnota spoteczna, dz. cyt., s. 20.

20 M. Dziewiecki, Ponowoczesność - cztowiek - wychowanie, dz. cyt.

21 M. Stepulak, Relacyjność sytemu rodzinnego, „Roczniki Teologiczne” 54 (2007) z. 10, s. 93-119. 
znaczy takich, które „cechuje ścisły i bezpośredni kontakt ich członków: nawiązują oni ze sobą bliskie stosunki emocjonalne, łączą ich trwałe i osobiste więzy, oparte na współdziałaniu i solidarności”22.

\section{Dar i ofiara jako przejaw solidarności}

Większość współczesnych kontaktów, które można postrzegać w kategoriach ekonomicznych, ma charakter wymienny. Bezinteresowne relacje osobowe często spychane są na dalszy plan. W szerokiej płaszczyźnie stosunków społecznych rządzących się zasadą „coś za coś”, to wymiana jest podstawowym zwornikiem i jej podporządkowane są prawie wszystkie sprawy. Niektóre formy tych kontaktów można określić „stosunkami daru” a contrario do stosunków wymiennych „coś za coś”. Relacje międzyludzkie, o których tu mówimy, nie podlegają żadnym ocenom ekonomicznym, poruszamy się w polu wartości etycznych. Obecnie jesteśmy świadkami ciągłego rozszerzania się reguły wzajemności we wciąż nowych i coraz liczniejszych dziedzinach. Oznacza to, że jest coraz więcej obszarów, z których zniknęło pojęcie daru jako zwykłej formy stosunków między ludźmi ${ }^{23}$.

Cnota solidarności wykracza poza dobra materialne ${ }^{24}$. Oparta jest na miłości, która uzdalnia do składania ofiar i okazywania gotowości do daru z siebie $^{25}$. Kluczowe jest tu zrozumienie faktu, że można także posiadać siebie i siebie ofiarować. Nie jest to doświadczenie jednostronne, gdyż wyraża się w gotowości oraz umiejętności przyjęcia czyjegoś daru. Wzajemność należy zatem do istoty ofiarowania - jako aktu dobrowolnego i niewymuszonego. Taka postawa ofiarności nadaje sens ludzkiemu życiu i świadczy o wewnętrznym bogactwie człowieka. Zwraca na to uwagę Viktor Frankl, który apeluje: „Musimy dzisiaj przywrócić pojęcie ofiary. Bez niego nie można mówić o sensownym życiu człowieka. Jego świat bez doświadczenia ofiary nie ma sensu i staje się neurotyczny"26. Z kolei Jan Paweł II mówi wręcz, że szczęście osiąga się tylko przez ofiarę ${ }^{27}$.

Analizę daru i ofiary należy rozważać w kontekście posiadania, bowiem żeby coś dać, trzeba to najpierw mieć. Nie można ofiarować czegoś, co nie

22 J. Rembowski, Rodzina wświetle psychologii, Warszawa 1986.

23 P. Dembiński, Odkryć na nowo ekonomię daru, „Więź” 4 (1988), s. 105-111.

24 KKK, nr 1942.

25 A. Derdziuk, Solidarność jako cnota spoteczna, dz. cyt., s. 24.

26 K. Grzywocz, Bogate człowieczeństwo i postawa ofiary, „Życie Duchowe” 20 (2013) nr 73, s. 7-12.

27 Jan Paweł II, Msza św. na placu Ignacio Agramonte, 23.01.1998. 
jest moją własnością. Tu może pojawiać się opór, lęk przed straceniem tego, co ofiaruję. Niemniej jednak nie ma ofiary bez wyrzeczenia, bólu, cierpienia. Cierpienie związane z postawą ofiary może mieć różne oblicza: rezygnacji, oddania, nieprzyjęcia, poniżenia, odrzucenia, zmęczenia ${ }^{28}$. Nietrudno też zauważyć, że najcenniejszych dóbr, jakie posiadamy, nie można nabyć za pieniądze - przyjaźń, udane małżeństwo, kapłaństwo, wierność, mądrość, nadzieja ${ }^{29}$. Ograniczanie „ofiar” jedynie do tego, co można kupić, prowadzi ostatecznie do rozczarowania, głębokiego niedosytu i niespełnienia. Pozostanie jedynie fenomen prezentu, za którego wielkością ukryte będzie sfrustrowane pragnienie daru i ofiary. Dochodzimy tu do fundamentalnej prawdy, że darem może być osoba, natomiast prezent to rzecz, czyli rzeczywistość nieosobowa. Tam, gdzie człowiek nie jest darem, tam wzrasta wartość prezentów. W konstelacji „prezent - dar - ofiara” droga od prezentu do ofiary prowadzi przez personalizację daru, to znaczy doświadczenia, że tym, czego najbardziej pragniemy, jest osoba, a nie rzecz ${ }^{30}$.

Oddanie, służba i ofiara są doświadczeniami, które w najgłębszy sposób nadają sens ludzkiemu przemijaniu. Niestety współczesny człowiek poddawany jest destrukcyjnemu wpływowi niepewności egzystencjalnej i często nie przyjmuje faktu przemijania oraz swojej skończoności. Natomiast natura jest procesem nieustannej odnowy, wyrażającym wieczną młodość świata, ciągłym zaczynaniem od początku, niekończącą się sukcesją świtów. Jest też ona zarazem różnorodnością, która rozpoczyna się wciąż od coraz to nowych, pojedynczych bytów. Różnorodność, jednostkowość, nadzieja możliwe są jedynie dzięki akceptacji śmierci. Stoi to w sprzeczności z dewizą współczesnego człowieka, powtarzającego niczym rozwścieczony mały chłopiec „ja”, ,ja”, ,ja” ${ }^{31}$.

Nieuchronność przemijania człowieka należy rozumieć przez pryzmat ewangelicznej metafory obumierającego ziarna: „Jeżeli ziarno pszenicy wpadłszy w ziemię nie obumrze, zostanie tylko samo, ale jeżeli obumrze, przynosi plon obfity” (J 12, 24). „Cóż bowiem mówi nam ta metafora? Nie tylko to, że nasza egzystencja nie ma charakteru monadycznego, lecz jest byciem dla innych. Wysławia ona również prawdę o paradoksie egzystencji etycznej: obdarowując innych, nie zatracamy i nie pomniejszamy siebie, ale

\footnotetext{
28 K. Grzywocz, Bogate człowieczeństwo i postawa ofiary, dz. cyt., s. 7-12.

29 K. Grzywocz, Bogate cztowieczeństwo i postawa ofiary, dz. cyt., s. 7-12.

30 A. Derdziuk, Solidarność jako cnota społeczna, dz. cyt., s. 24.

31 Ch. Delsol, Nienawiść do świata, Instytut Wydawniczy Pax, Warszawa, s. 205.
} 
- paradoksalnie - budujemy i ocalamy siebie" ${ }^{32}$. Wybór siebie jako ziarna pszenicznego jest decyzją przyjmowania swego powołania, służenia wartościom, życia dla innych, miłowania, a nawet ofiary. A to implikuje obumieranie człowieka - wyrzeczenie, trud. Jednak obumieranie nie jest celem, lecz $\operatorname{drogą}^{33}$. Zadanie nieustannej odnowy, powołanie do tworzenia wszystkiego ciągle od nowa jest związane z pogodzeniem się ze śmiercią. Nasi przodkowie, starzejąc się, mówili: „Trzeba zrobić miejsce młodym”. Wykazywali się $\mathrm{w}$ pewnym sensie solidarnością z kolejnymi pokoleniami ${ }^{34}$.

Warto zwrócić uwagę na jeszcze jeden aspekt. Jak już wcześniej wspomniano, solidarność jest taką postawą, której istotę można określić jako bezinteresowne dawanie. Często jednak dochodzi do wypaczenia tej zasady. To, co powinno być darem, często w oczach obdarowanego staje się czymś, co mu się po prostu należy i za co nie ma powodu dziękować. Liczę się tylko „ja” i mój punkt widzenia. A kto się $\mathrm{z}$ nim nie zgadza - ten narusza fundamentalne prawo jednostki. Dziś taka coraz bardziej radykalnie rozumiana ideologia „prawa jednostki” do destrukcji wszelkich zastanych więzi społecznych i kulturowych staje się normą, zasadą ${ }^{35}$. Musimy jednak pamiętać, że pogoń za utopią indywidualistycznego szczęścia musi prowadzić do odwrotnych skutków, czyli do powierzchowności w stosunkach międzyludzkich, do kryzysu więzi i zupełnej obojętności na los drugiego człowieka, do braku wrażliwości na potrzeby innych, do niezdolności do współpracy, do nadmiernej koncentracji na samym sobie, do postaw egoistycznych i cynicznych, do walki każdego z każdym ${ }^{36}$.

\section{Specyfika społeczności wiejskiej}

Współczesna wieś polska zmienia się, staje się otwarta i coraz trudniej określić, co składa się na wiejskość. Niemniej jednak obraz wsi utrwalony w literaturze etnologicznej ujawnia tendencję do traktowania jej jako wspólnoty lokalnej, gdzie występuje specyficzny styl życia, silne więzi rodzinne i sąsiedzkie, bezpośrednie kontakty face to face, pomoc sąsiedzka, „swojskość” ludzi, lokalny kod kulturowy, tradycje, zwyczaje ${ }^{37}$. Do cech dystynktyw-

32 J. Galarowicz, Zobaczyć w Bogu Człowieka, dz. cyt.

33 J. Galarowicz, Antropodramatyka Karola Wojtyty, „Studia Humanistyczne AGH” 5 (2007), s. 31.

34 Ch. Delsol, Nienawiść do świata, dz. cyt., s. 205.

35 A. Nowak, Triumfjednostki nad wspólnota i dewiacji nad rozumem, „WPiS” (2021) nr 3 (125), s. 14.

36 M. Dziewiecki, Ponowoczesność - człowiek - wychowanie, dz. cyt.

37 M. Dziura, Lokalne współdziałanie - pomoc sąsiedzka dawniej i dziś, „Tematy z Szewskiej” (2012) $\operatorname{nr} 1$ (7), s. 57-69. 
nych mieszkańców wsi należy też powszechne uczestnictwo w miejscowym życiu towarzyskim i celebrowanie lokalnych obrzędów, poczucie solidarności i oparcia.

Typowa społeczność wiejska jest tradycyjna i nieduża, wszyscy znają tu zarówno swoje usytuowanie społeczne, jak i swoich sąsiadów. Życie składa się z kontaktów lokalnych ze stosunkowo niewielką liczbą wciąż tych samych, dobrze znanych ludzi, wedle stałych wzorów. Niemniej jednak kontakty te są bogate, częste, intensywne ${ }^{38}$. Wspólny obszar sprawia, że ludzie wchodzą ze sobą w rożne relacje i zależności oraz są połączeni przez więzi krewniacze, sąsiedzkie, a nawet lokalne. W tworzeniu wspólnot podkreśla się aspekt terytorialności, czyli przestrzeni i miejsca. Egzystencja skupia się na określonym terenie, w homogenicznych zbiorowościach stanowiących względnie zamknięty system. Ta wspólna przestrzeń wpływa na powstanie struktury sieci powiązań międzyludzkich, różnorodnych więzi, zwyczajów, obyczajów, tradycji. Lokalność ujawnia się w takich zjawiskach jak: pomoc sąsiedzka, odrobek, nieufność wobec obcych, emocjonalna i sentymentalna wartość ziemi ${ }^{39}$.

Wyróżniającą cechą społeczności wiejskiej jest język. Mowa charakterystyczna dla tej wspólnoty pełni funkcję komunikacyjną, jest spoiwem łączącym jednostki w regionalną społeczność, pełni też funkcję identyfikującą tę zbiorowość i jest składnikiem jej kultury. W małej społeczności o właściwościach wspólnoty naturalnej, jaką jest rodzina, słowo jest elementem niezbędnym do budowania emocjonalnych więzi między jej członkami. Słowo jest czymś, co istniało od początku dziejów człowieka, czymś, co porównywać można do takich funkcji życiowych jak oddychanie i jedzenie. Musi zatem istnieć od najwcześniejszego stadium życia człowieka, gdyż należy do filarów, na których wspiera się świat i wszelka ludzka egzystencja ${ }^{40}$.

Analiza społeczności wiejskiej musi koncentrować się wokół rodziny, bowiem stanowi ona fundament wspólnoty lokalnej. To wokół tej podstawowej jednostki życia społecznego koncentruje się wiejskie życie, zatem jej rola w kształtowaniu postaw solidarności międzyludzkiej jest oczywista. Budowanie wspólnoty następuje w pierwszej kolejności w rodzinie, która jest pierwszym i podstawowym środowiskiem wychowawczym, a tym samym

38 B. Szacka, Wprowadzenie do socjologii, Oficyna Naukowa, Warszawa 2003, s. 25.

39 M. Dziura, Lokalne współdziałanie - pomoc sąsiedzka dawniej i dziś, dz. cyt., s. 57-69.

40 K. Neugebauer, Potrzeby emocjonalne cztowieka w pierwszej fazie życia, „Chrześcijanin w świecie” 95-96 (1980), s. 33-42. 
miejscem kształtowania takich postaw jak miłość, odpowiedzialność czy solidarność. W rodzinie człowiek uczy się współpracy, relacji, współzależności, a przez to gotowości do służby drugiemu. Wynika to z faktu, iż główną treścią przekazu międzypokoleniowego jest system wartości, w tym wzorce osobowe $\mathrm{e}^{41}$.

Od stuleci więzy krwi decydowały o przynależności jednostek do wspólnot, a naruszenie lojalności między krewnymi było postrzegane jako największa niegodziwość. We wspólnocie wiejskiej więzi rodzinne przenikały się z sąsiedzkimi w ramach rodziny poszerzonej. Wiejską wspólnotę definiowano wręcz jako społeczność rodzin. Jako że rodzina skoncentrowana była wokół gospodarstwa rolnego, każdy jej członek miał wobec tego gospodarstwa obowiązki, a praca była podstawowym narzędziem socjalizacji. Wypracowany był model, wedle którego każdy członek rodziny odpowiadał za pozostałe osoby. Rodzice byli odpowiedzialni za liczne potomstwo, które z kolei miało świadomość konieczności pracy na rzecz całej rodziny. Wszyscy członkowie społeczności rodzinnej solidarnie pracowali dla wspólnego dobra, często tym dobrem było przeżycie ${ }^{42}$. Bez wzajemnej odpowiedzialności każdy za każdego rodzina nie przetrwałaby. Nie bez znaczenia jest też fakt, że rodziny wiejskie zazwyczaj były wielodzietne, co z pewnością sprzyjało wyrabianiu nawyków współpracy, współżycia, wzajemnej odpowiedzialności. Jako czynnik spajający rodzinę można wskazać przykład spożywania wspólnych posiłków z jednej miski.

Według Danuty Markowskiej do cech charakterystycznych tradycyjnej rodziny chłopskiej należą: ścisły związek z warsztatem rolnym; jedność interesów rodziny $\mathrm{z}$ interesami gospodarstwa; ogniskowanie się wszystkich podstawowych funkcji rodziny wokół jej funkcji gospodarczych; nierozerwalność związku małżeńskiego traktowanego jako instytucja sakralna, powołana do spłodzenia potomstwa i wspólnego osiągania celów gospodarczych; patriarchalizm w stosunkach wewnątrzrodzinnych, a także w zewnętrznych stosunkach rodziny; niesamodzielność pojedynczej rodziny - jej zależność i współzależność w systemie krewniaczo-sąsiedzkim; uniformizm rytmu życia rodzinnego; rygoryzm wzorów kulturowych określających role i zadania poszczególnych członków rodziny ${ }^{43}$.

41 P. Żebrok, Rodzina w systemie społeczno-kulturowym Śląska Cieszyńskiego. Studium teoretyczno-badawcze, Wydawnictwo „Scriptum”, Kraków 2018, s. 167.

42 Nasuwają się tu słowa św. Pawła: „Kto nie chce pracować, niech też nie je!” (2 Tes 3, 10).

43 D. Markowska, Rodzina w środowisku wiejskim, Ossolineum, Wrocław-Warszawa-Kraków 1964. 
Solidarność wiejska często była wymuszana przez ściśle określone zasady. Warto tu wspomnieć o solidarności międzypokoleniowej. Przykładem niech będą dawne zapisy w aktach notarialnych, precyzyjnie określające reguły współżycia w rodzinie po przepisaniu gospodarstwa (domu, pola). Czymś naturalnym i oczywistym jest obowiązek opieki nad ludźmi starymi w rodzinie, przy czym powszechnie nieakceptowalne jest umieszczanie rodziców w zakładach opiekuńczych czy domach starców. Jest to zasada głęboko zakorzeniona w świadomości ludzi wsi.

\section{Przykłady solidarności wioskowej}

Przedstawione przykłady solidarności wioskowej dotyczą zasadniczo drugiej połowy XX wieku. Niektóre zostają tu przytoczone jako przykłady zjawisk, których już nie ma, a zostały tylko w pamięci starszych mieszkańców. Inne, jak na przykład pomoc sąsiedzka, ciągle są obecne i żywe.

Pomoc sąsiedzka wywodzi się $\mathrm{z}$ dawnego prawa zwyczajowego, wedle którego każdy, kto znajdzie się w potrzebie, może liczyć na mieszkańców swojej wioski. Pomoc ta okazywana jest w codziennym życiu wiejskim i przejawia się przede wszystkim w rożnych czynnościach gospodarczych świadczonych na rzecz dobra wspólnego wsi ${ }^{44}$. Przybiera bardzo różnorodne formy, np. pomoc w pracach sezonowych związanych z rokiem gospodarczym, pracach polowych, gospodarskich, przy wznoszeniu budynków, przygotowaniu rożnych uroczystości, „szkubaczkach” (darciu pierza).

Obowiązek wzajemnej pomocy ciąży na mieszkańcach wsi w wypadkach szczególnych, zwłaszcza w sytuacjach klęsk żywiołowych i nieszczęść. Zarówno dawniej, jak i dzisiaj z pomocą poszkodowanemu rusza cała wieś, zwłaszcza najbliższe sąsiedztwo. Wzajemna pomoc w takich przypadkach to trwale zakorzenione zachowania na wsi. Na przykład funkcjonują zbiórki materialne dla potrzebujących nie tylko ze swojej wioski, ale także z odległych miejscowości.

Pomoc sąsiedzka nasila się w sytuacjach wyjątkowych i uroczystych. Okazją do współdziałania i bezinteresownej pomocy są pogrzeby, wesela oraz inne uroczystości i wydarzenia rodzinne. Przygotowania do wesela angażują najbliższe sąsiedztwo. Znosi się produkty spożywcze (jajka, sery, mąkę, masło itp.), pomaga w pieczeniu, gotowaniu, dekorowaniu sali biesiadnej, 
ustawianiu podłogi do tańca ${ }^{45}$. Obecnie coraz częściej rezygnuje się z takiej formy organizowania przyjęć, niemniej jednak wciąż się zdarzają. Wśród przykładów bezinteresownej pomocy można wymienić pieczenie „kołoczy” na wesele. Wypieki są rozdzielane wśród rodziny, sąsiadów, znajomych.

Wzajemność świadczeń, która wynika z solidarności gromadnej, życzliwości i konieczności terminowego wykonania prac polowych, jest przejawem więzi społecznych i nie opiera się na konkretnej kalkulacji. Reguluje ją dewiza: „dziś ty mnie, jutro ja tobie”. Nie zawsze jest to pomoc bezinteresowna, ale swoiste ubezpieczenie na wypadek własnego nieszczęścia lub konieczności użycia większych sił roboczych. Wszystkie te prace wykonuje się bezpłatnie, często za poczęstunek, który na wsi jest bardzo ceniony. Pieniędzmi rzadko płaci się za pracę. Odwzajemnienie pracy jest obowiązkiem, honorem, powinnością ${ }^{46}$.

Bardzo dużo zachowań budujących i podtrzymujących relacje wiąże się z pracami na roli i w gospodarstwie. Można tu wymienić przede wszystkim sąsiedzką pomoc przy różnych pracach w polu (zbieranie ziemniaków, owoców, praca przy żniwach). Niektóre zachowania zostały już tylko w formie przekazu ustnego. Należy do nich tzw. „sprzężaj”, polegający na tym, że do niektórych prac potrzeba było dwóch koni, więc popularne było ich „sprzęganie”. Posiadacze koni wchodzili ze sobą w ścisłe zależności. Odrabiali swoje usługi najczęściej tym samym świadczeniem, np. pomocą przy orce w polu. Ci, którzy korzystali z pracy sprzęgniętych koni, musieli świadczyć pomoc sąsiedzką obu właścicielom.

Relacje między gospodarzami na wsi kształtuje wymiana świadczeń i równowaga usług, a także „odrobek”, czyli praca za pracę lub inne świadczenia. Dawniej biedni chłopi wraz z całymi rodzinami pracowali w gospodarstwie innego gospodarza w zamian za jakieś świadczenie lub usługę ofiarowaną przez właściciela tego gospodarstwa, np. pracę końmi, pożyczenie zboża, narzędzi, możliwość użytkowania łąk, pastwisk, dzierżawę pola.

$\mathrm{Na}$ wsi czymś naturalnym i oczywistym jest dzielenie się. Powszechnie znane i praktykowane są dary obrzędowe (obdarzanie nowożeńców, położnicy, chrześniaków, rodziny zmarłego). Jednym z przykładów ciągle żywego na Śląsku Cieszyńskim zwyczaju bezinteresownego dzielenia się jest odwiedzanie nowo narodzonego dziecka z „nowiyckóm”. Rodzina i sąsiedzi 
przynoszą młodej matce i jej dziecku potrzebne ubrania, pieluchy, zabawki. $\mathrm{Z}$ narodzinami dziecka wiąże się też zwyczaj obdarowywania matki w połogu kurą na rosół.

"Zabijaczka”, czyli świniobicie, to jedno z najważniejszych wydarzeń $\mathrm{w}$ życiu rodziny. Jest to okazja do dzielenia się mięsem oraz wyrobami z rodziną i sąsiadami. Ci z kolei odwzajemniają się w ten sam sposób, kiedy u nich jest podobne wydarzenie. Osobom biednym, samotnym, niehodującym zwierząt sąsiedzi przynoszą czasem trochę mleka, masła, sera itp., nie oczekując w zamian żadnej zapłaty. Wśród zachowań, które już zanikły, trzeba wymienić umożliwienie ludziom biednym zbierania kłosów po żniwach. Celowo nie grabiono dokładnie ścierniska, aby umożliwić zbiórkę kłosów potrzebującym. Podobnie było z wypasem owiec na oziminach przez wędrujących górali.

Do ważnych elementów współpracy sąsiedzkiej należą pożyczki. Dawniej pożyczano sobie wiele: chleb, kaszę, mąkę, naczynia, narzędzia - wszystko, co w danej chwili było potrzebne, a czego brakowało. Przykładem może być pożyczanie formy do pieczenia baranka wielkanocnego, „noże” do szatkowania kapusty, „konkordyja”. Były to sprzęty, które nie każdy musiał posiadać. Chociaż miały właściciela, służyły dużej grupie sąsiadów. Na wsi powszechna jest też wymiana zboża na siew i innych płodów rolnych oraz urządzeñ ${ }^{47}$.

Za bardzo ważny wśród mieszkańców wsi należy uznać zwyczaj odwiedzania się. Dotykamy tu wcześniej poruszanego zagadnienia „dawania siebie”. Okazje mogą być różne: odpusty, imieniny, urodziny, święta czy też choroba. Dawniej bardzo popularne było chodzenie „po winszu” czy „wygrowani na miano", w Nowy Rok można było spotkać kolędników. Jednym ze zwyczajów są odwiedziny w Wielki Piątek z „tatarczówką”, czyli bardzo gorzką wódką wyrabianą na bazie korzenia tataraku. Podobnie w wigilię Bożego Narodzenia jednym ze zwyczajów jest częstowanie „wilijówką”. Tego typu poczęstunki mają charakter raczej symboliczny i służą budowaniu czy też podtrzymywaniu więzi. Dzielenie się swoją obecnością, życzeniami, umiejętnościami (gra na instrumencie) odwzajemniane jest poczęstunkiem, drobnymi podarunkami, pieniędzmi. Szczególnie wyczuleni na tego typu spotkania są starsi mieszkańcy wsi.

Wśród zachowań przyczyniających się do budowania solidarności wiejskiej są wszelkiego rodzaju obrzędy religijne. Można powiedzieć, że wiara 
spaja ludzi wsi. Wspólne majówki przy kapliczkach przydrożnych, październikowy różaniec, procesje itd. pozwalają utrwalać i wzmacniać relacje i wioskową solidarność. Na wsi ludzie potrafią się zorganizować przy budowie ołtarzy na Boże Ciało czy Bożego grobu na Wielkanoc. Takie wydarzenia jak pogrzeb to czas wspólnej modlitwy, odmawiania różańca. Później praktykowany jest wspólny posiłek, czyli stypa. Trzeba nadmienić, że na Śląsku Cieszyńskim mieszkańcy wszystkich wyznań solidarnie uczestniczą w pogrzebach każdego członka społeczności wiejskiej.

Warto też wspomnieć o działalności wiejskich organizacji, które zawiązują wspólnoty i budują trwałe relacje. Można tu wymienić Koła Gospodyń Wiejskich, Ochotnicze Straże Pożarne, Ludowe Kluby Sportowe.

Współdziałanie na wsi ma bardzo liczne formy i wynika nie tylko z potrzeby osiągnięcia konkretnego celu, ale też bycia razem. Wspólne działanie konsoliduje wieś i w pewien sposób uzależnia jednych od drugich. Wymienione formy kontaktów międzyludzkich nie podlegają ocenom ekonomicznym, lecz moralnym, i należy je traktować w kategoriach „daru” - w przeciwieństwie do wspomnianych wcześniej stosunków wymiennych.

\section{Zakończenie}

Gospodarstwo wiejskie zawsze wykazywało cechy względnej stałości i trwałości. Stanowiło ono wraz z rodziną jedność produkcyjną i społeczną utrzymującą ciągłość wzorów kulturowych w długotrwałym procesie historycznym. Rytm życia mieszkańców wyznaczały pory roku, dni tygodnia, święta religijne. Niektóre zachowania były przekazywane z pokolenia na pokolenie i stawały się naturalne, jakby wrodzone, dziedziczone genetycznie.

Wraz z przeobrażeniami współczesnego świata zmienia się polska wieś, a co za tym idzie, ograniczenie przekazu dotychczasowych wzorów kultury. Jest to widoczne zarówno w wymiarze indywidualnym, jak i społecznym. Przede wszystkim zmniejsza się rola rodziny w zakresie wielu funkcji, które pełniła dawniej na rzecz społeczeństwa i swych członków. Zmiana modelu życia powoduje, że rodziny zamieszkują samodzielnie, bez dziadków, stąd kontakt ze starszym pokoleniem jest rzadszy i luźniejszy. Pojawia się większa ruchliwość mieszkańców wsi, czyli migracje, zmieniają się stosunki sąsiedzkie i krewniacze. Do tego dochodzą takie zachowania jak zmiana sposobów i kanałów komunikacji, ograniczenie osobistych relacji na rzecz różnego rodzaju komunikatorów, przepotężny wpływ mediów, globalizacja i unifikacja 
kultury. Mieszkańcy wsi ulegają kulturze globalnej, oferującej ujednolicone wzory kulturowe, zunifikowany styl życia i taką samą - powierzchowną i płytką - tożsamość. W miejsce tradycyjnych wartości, takich jak solidarność, ofiarność, wspólnota, pojawiają się zupełnie inne, jak indywidualizm, efektywność, sukces. Konsekwencją tego jest zanik zasad i wartości, które dotychczas stanowiły fundament życia społecznego. Czas pandemii przyniósł też sporo innych zagrożeń, niesprzyjających podtrzymywaniu lokalnych wspólnot.

Obserwacja współczesnej wsi skłania do refleksji i stawiania pytań. Czy więzi międzyludzkie przetrwają, czy grozi nam koniec solidarności wśród ludzi? Chantal Delsol widzi tę przyszłość pesymistycznie. Jak zauważa, społeczeństwo, ku któremu zmierzamy, jest niezwykle zhierarchizowane i raczej obojętne na obowiązek solidarności. Społeczeństwo, które tworzy solidarne grupy, jest albo holistyczne, albo chrześcijańskie (albo i jedno, i drugie). Nie jesteśmy już ani pierwszym, ani drugim ${ }^{48}$.

\section{Bibliografia}

Delsol Ch., Czas wyrzeczenia, Państwowy Instytut Wydawniczy, Warszawa 2020.

Delsol Ch., Nienawiść do świata, Instytut Wydawniczy Pax, Warszawa 2017.

Dembiński P., Odkryć na nowo ekonomię daru, „Więź” 4 (1988), s. 105-111.

Derdziuk A., Solidarność jako cnota społeczna, „Roczniki Teologii Moralnej” (2012) nr 4 (59), s. 19-29.

Dziewiecki M., Ponowoczesność - cztowiek - wychowanie, https://opoka.org.pl/biblioteka/I/ID/ponowoczesnosc_wychowanie.html (6.03.2021).

Dziura M., Lokalne wspótdziałanie - pomoc sąsiedzka dawniej i dziś, „Tematy z Szewskiej" (2012) nr 1 (7), s. 57-69.

Galarowicz J., Antropodramatyka Karola Wojtyty, „Studia Humanistyczne AGH” 5 (2007), s. 23-33.

Galarowicz J., Zobaczyć w Bogu Cztowieka, „Azymut” (2002) nr 4 (49).

Gide K., Solidaryzm, Lwów 1908.

Grzywocz K., Bogate cztowieczeństwo ipostawa ofiary, „Życie Duchowe” 20 (2013) nr 73, s. $7-12$.

Jan Paweł II, Fragment homilii wygłoszonej przez podczas mszy świętej dla świata pracy, Gdańsk, 12.06.1987.

48 Ch. Delsol, Czas wyrzeczenia, Państwowy Instytut Wydawniczy, Warszawa 2020, s. 330. 
Jan Paweł II, Msza św. na placu Ignacio Agramonte, 23.011998.

Jan Paweł II, Pielgrzymki do Ojczyzny, Kraków 2005.

Jan Paweł II, Encyklika Sollicitudo rei socialis, Rzym 1987.

Jan Paweł II, Encyklika Centesimus annus, Rzym 1991.

Katechizm Kościoła katolickiego, Pallottinum, Poznań 1994.

Koneczny F., Polskie logos a ethos, Antyk, Komorów 1996.

Markowska M., Rodzina w środowisku wiejskim, Ossolineum, Wrocław-WarszawaKraków 1964.

Neugebauer K., Potrzeby emocjonalne cztowieka wpierwszej fazie życia , „Chrześcijanin w świecie" 95-96 (1980), s. 33-42.

Nowak A., Triumf jednostki nad wspólnota i dewiacji nad rozumem, „WPiS” (2021) nr 3 (125), http://e-wpis.pl/pl/triumf-jednostki-nad-wspolnota-i-dewiacji-nadrozumem-(2.11.2021).

Pius XII, Encyklika Summi pontificatus, Rzym 1939.

Radzińska J., Solidarność: definicja i konteksty, „Etyka” 48 (2014), s. 58-68.

Rembowski J., Rodzina ws świetle psychologii, Warszawa 1986.

Stepulak M., Relacyjność sytemu rodzinnego, „Roczniki Teologiczne” 54 (2007) z. 10, s. 93-119.

Szacka B., Wprowadzenie do socjologii, Oficyna Naukowa, Warszawa 2003.

Tischner J., Etyka solidarności. Homo sovieticus, Znak, Kraków 2005.

Żebrok P., Rodzina w systemie społeczno-kulturowym Śląka Cieszyńskiego. Studium teoretyczno-badawcze, Wydawnictwo „Scriptum”, Kraków 2018.

\section{Abstrakt}

\section{Gen solidarności w polskiej społeczności wiejskiej}

W ciągu ostatnich kilkudziesięciu lat na polskiej wsi dokonały się gwałtowne przemiany we wszystkich obszarach życia. To nie tylko zmiany w sposobie życia i gospodarowania, ale przede wszystkim przeobrażenia w szeroko pojętej kulturze, religijności, moralności, obyczajowości. Pomimo jednak tej rewolucji, mieszkańcy wsi zachowali pewne cechy (kod genetyczny), które dotyczą życia wspólnotowego. Niektóre - ciągle żywe w społeczności wiejskiej-zachowania świadczą o trwałych więzach wspólnotowych, będących z kolei fundamentem solidarności.

Opracowanie podejmuje zagadnienia solidarności w polskiej społeczności wiejskiej. Koncentruje się na kilku ważnych aspektach dotyczących tego fenomenu 
relacji międzyludzkich. Przede wszystkim solidarność przedstawiona zostaje jako cnota wybitnie chrześcijańska, zaś jej podstawową cechą jest relacyjność. Podjęto także próbę opisania tego zjawiska w kategoriach daru i ofiary. Oprócz teoretycznych rozważań w opracowaniu przytoczono konkretne przykłady zachowań świadczących o solidarności wśród ludzi na wsi.

Słowa kluczowe

solidarność, wspólnota, rodzina, społeczeństwo, wieś. 